\title{
Implementation of Controller for PMBLDC Motor Drive based Electric Vehicle
}

\author{
D.Susitra, Suragani Thirupathi Rao, Pasala Bobby Sudheer
}

\begin{abstract}
The entire research community working on automobiles have turned their focus on electric vehicle. $P M B L D C$ motor is very popular in industrial and household applications due to its high efficiency, high power density and low maintenance cost. The rapid advancement in power electronics devices and controllers aids the use of PMBLDC motor in electrical drives system instead of conventional $D C$ motor and AC motor. In this paper we have discussed a Simulink model of Bi-directional speed control for high torque to volume ratio PMBLDC motor to control the speed of PMBLDC motor in electric vehicle application. In this scheme the direction of motor is changed only with change in switching pattern. So this method is a cost effective method. The same strategy has been implemented using DSPIC4011, 16 bit microcontroller. The Raspberry Pi acts as a gateway to configure the unique ID for the application and connect it with the web server. The device is capable of sending the sensor value to the database and the user can able to monitor the value in the web page.
\end{abstract}

Index Terms: Electric Vehicle, PMBLDC Motor, DSPIC Controller, IoT Tech.

\section{INTRODUCTION}

People pay high attention on zero-pollution electrical vehicles (EV) with development of environmental protection consciousness. An EV system consists of an electric motor, power controller unit and battery for power back up [1]. The increase in demand of electric vehicles requires compact motors having higher torque, the good option for this kind of Vehicle,.among all the driving motors, the permanent magnet brushless DC (PMBLDC) machine exhibits better performance compared with conventional DC motors with brush and other AC Motors [2][3]. The salient features of Brushless dc motors (BLDCM) are its simple structure, high starting torque and speed with higher efficiency, good dynamic response, reduced noise and reliability [11][12].

The PMBLDC motor can be driven with the c-dump topology to obtain the four quadrant operation with cost minimization and simple structure [7]. Permanent magnet motor with trapezoidal and sinusoidal back EMF has

Revised Manuscript Received on October 12, 2019

D.Susitra, Dept. of EEE, Sathyabama Institute of Science and Technology ,Chennai,India

Suragani Thirupathi Rao, Dept. of EEE, Sathyabama Institute of Science and Technology,Chennai,India

Pasala Bobby Sudheer, Dept. of EEE, Sathyabama Institute of Science and Technology, Chennai,India several advantages such as increased efficiency and less maintenance over other conventional motors such as AC induction motors and DC motors with brushes [8]. These conventional motors when substituted with better efficient permanent magnet brushless dc (PMBLDC) motors benefit in considerable saving of energy, low maintenance, compact size, reduced consumption of fuel and, The use of these motors will result in less space, less fuel consumption and superior power to volume ratio [5][6]. Characteristics and parameters of this Motor is presented in [4].

In this paper the mathematical model of PMBLDC motor is discussed. PMBLDC drive is energized through a chopper circuit that is triggered via DSP controller. In so many applications, like automotive and robotics, the speed control of PMBLDC is required in both directions [9]. In such a system, the drive requires the precise output as per the user input in both directions. So the preceding sections discusses about the PWM based speed control of PMBLDC motor in both the directions [10]. In [14][15],the location information is communicated to mobile device using GSM from the longitude and latitude information from GPS. In Section II, the Block diagram of Electric vehicle along with its IOT implementation is discussed. Section III presents the Simulation circuits and results. Section IV presents the hardware implementation and summarized in section $\mathrm{V}$.

\section{SYSTEM OVERVIEW OF ELECTRIC VEHICLE}

\section{A. Block diagram of Existing System}

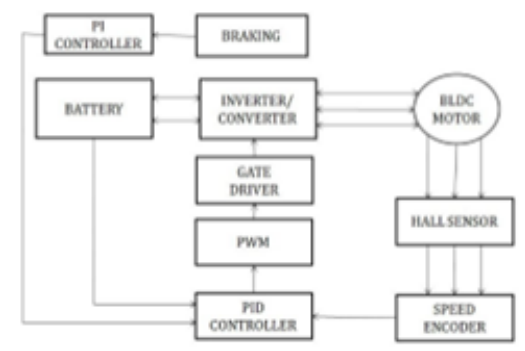

Fig.1 Blok Diagram of existing system

B. Block Diagram of Proposed System 


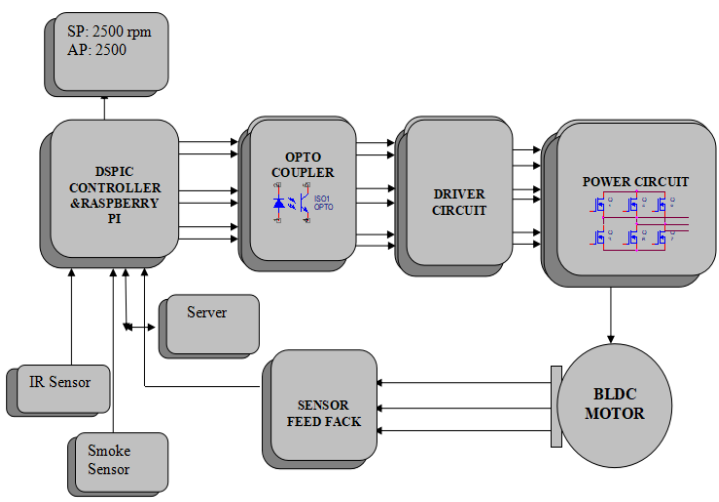

Fig. 2 Block diagram of proposed system

\section{PMBLDC Motor}

As the name implies PMBLDC motor has no brushes and hence free of maintenance due to wear and tear. The phases of the stator windings are energized through converter circuit with the desired phase sequence which is controlled through a preprogrammed controller.

D. IoT Implementation

Ultrasonic sensor: This Sensor is used to determine the distance from an object. This is achieved by the sensor by sending a sound pulse of high frequency towards the object. Then the time taken for the echo to reach back is measured and from this, the distance of the object is estimated. It has two cavities, one is for transmitting the waves and the other for receiving it back. The distance measurement at inaccessible areas is a typical application of the ultra-sonic sensor. This is usyally mounted on the stepper motor which gives the specified angle rotation to identify the objects present over that particular region.

Smoke sensor: The main application of the smoke sensor is to detect the harmful gases. This can be set by the threshold value using the potentiometer. Gas sensor is mainly sensitive to flammable gases/combustible gases like LPG, Propane and hydrogen

E. Comparison of PMBLDC with PMSM motor

Table 1 Comparison of BLDC with PMSM motor

\begin{tabular}{|l|l|}
\hline \multicolumn{1}{|c|}{ BLDCM } & \multicolumn{1}{|c|}{ PMSM } \\
\hline Synchronous machine & Synchronous machine \\
\hline Fed with direct currents & Fed with sinusoidal currents \\
\hline Trapezoidal back emf & Sinusoidal back emf \\
\hline $\begin{array}{l}\text { Stator flux position commutation } \\
\text { each } 60^{\circ}\end{array}$ & $\begin{array}{l}\text { Continuous stator flux position } \\
\text { variation }\end{array}$ \\
\hline $\begin{array}{l}\text { Only two phases ON at the same } \\
\text { time }\end{array}$ & $\begin{array}{l}\text { Possible to have three phases ON at } \\
\text { the same time }\end{array}$ \\
\hline Torque ripple at the commutation & No torque ripple at the commutation \\
\hline $\begin{array}{l}\text { Low order current harmonics in the } \\
\text { audible range }\end{array}$ & $\begin{array}{l}\text { Fewer harmonics due to sinusoidal } \\
\text { excitation }\end{array}$ \\
\hline $\begin{array}{l}\text { High core losses due to harmonic } \\
\text { content }\end{array}$ & Less core loss \\
\hline Less switching losses & $\begin{array}{l}\text { High switching losses at the same } \\
\text { switching frequency }\end{array}$ \\
\hline $\begin{array}{l}\text { Control algorithms are relatively } \\
\text { simple }\end{array}$ & $\begin{array}{l}\text { Control algorithms are } \\
\text { mathematically intensive }\end{array}$ \\
\hline $\begin{array}{l}\text { Easier to control (six trapezoidal } \\
\text { states) }\end{array}$ & $\begin{array}{l}\text { More complex control (continuous } \\
3 \Phi \text { sine wave) }\end{array}$ \\
\hline Better for lower speed & Higher maximum achievable speed \\
\hline Noisy & Low noisy \\
\hline $\begin{array}{l}\text { Doesn't work with distributed } \\
\text { winding }\end{array}$ & $\begin{array}{l}\text { Work with low-cost distributed } \\
\text { winding }\end{array}$ \\
\hline
\end{tabular}

\section{Hardware requirements \\ Dc voltage source \\ Three phase BLDC motor $24 \mathrm{~V}, 50 \mathrm{~W}$ \\ $\checkmark \quad$ Power supply \\ - 3 phase AC inverter \\ - dsPIC30F4011 controller or FPGA \\ - Raspberry Pi 3 \\ - Data cable \\ Ethernet cable}

Software requirement

$\begin{array}{ll}\diamond & \text { MPLAB } \\ \diamond & \text { Compiler C30F } \\ \diamond & \text { Language C } \\ \diamond & \text { Mobaxterm } \\ & \text { Python }\end{array}$

\section{SIMULATION RESULTS}

A. Simulation for closed loop system

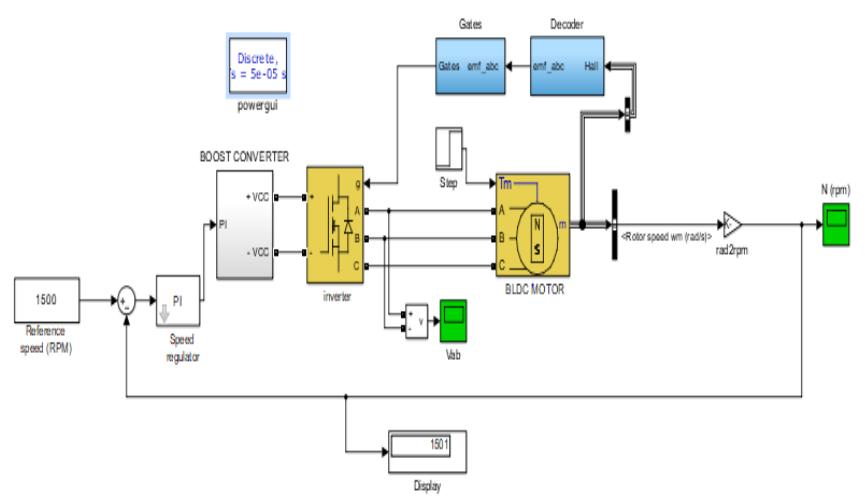

Fig.3 Simulation with PI controller 
Above shown simulation diagram includes the reference speed which the summer takes this speed and compares it with the actual speed of the BLDC motor. Based on the comparison made the error signal will be generated. It is given to the pi controller the PWM pulses will be generated with reference to the error signal given by the buffer. With the pulses received the MOSFETS gets ON and OF by then makes the phases of the BLDC to alternate $\mathrm{ON}$ and $\mathrm{OFF}$.

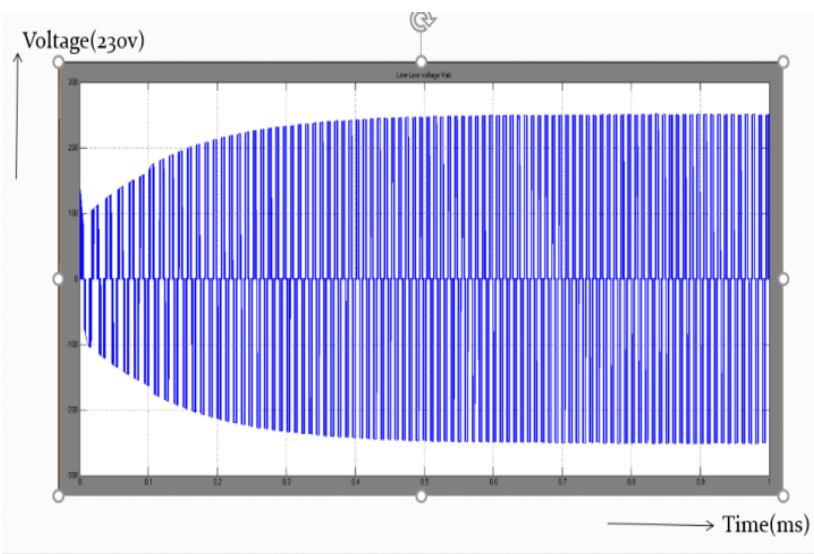

Fig. 4 Input voltage Vs Time

The above given graph shows that initially the voltage at the input side is $100 \mathrm{~V}$ and it gets increased slowly up to the rated value of $230 \mathrm{~V}$

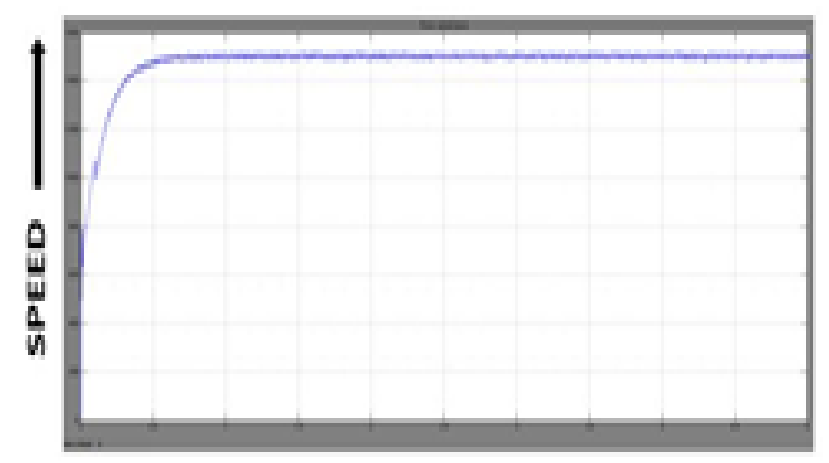

\section{TIME}

Fig. 5 Speed Vs Time

The above given graph speed Vs time shows that initially the motor speed increased up to the level of reference speed which is provided by the user and maintains it as the given system is a closed loop.

B. Simulation result of fuzzy logic controller

From the above we can see the voltage value starts increasing from the zero value and comes to the rated value with increase in time and maintains that standard voltage.

During the starting of the motor from rest the voltage of the motor is less in order to main tain the power constant the initial current will be to its peak value and come back to the limited value with time as the voltage gets increased. That can be seen from the below shown graph.

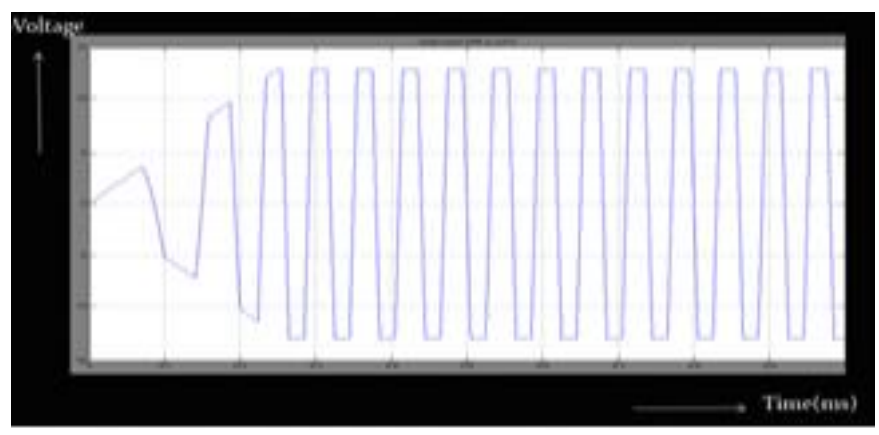

Fig. 8 Input voltage Vs Time 


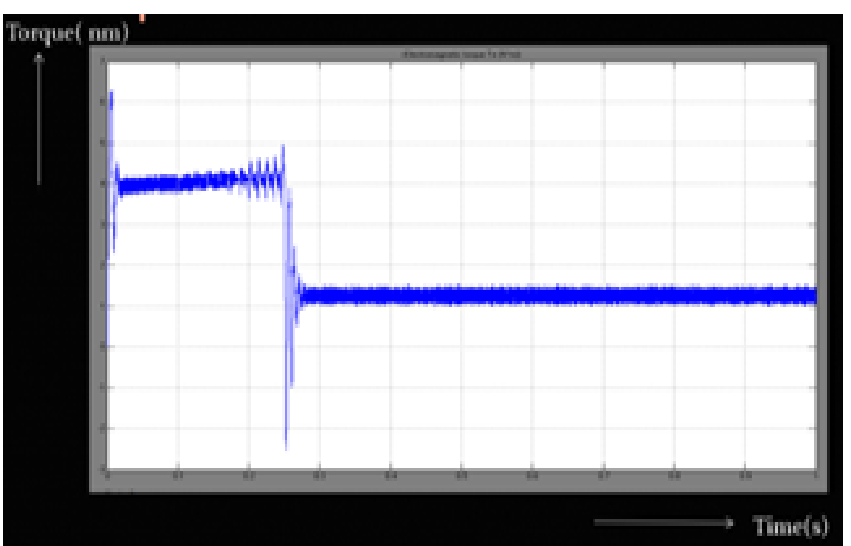

Fig. 9 Torque Vs Time

The figure says that the initial stating torque is greater than the toque required for the motor while running.

\section{HARDWARE}

\section{A. BLDC motor of $60 \mathrm{~W}, 3000 \mathrm{rpm}, 24 \mathrm{~V}$}

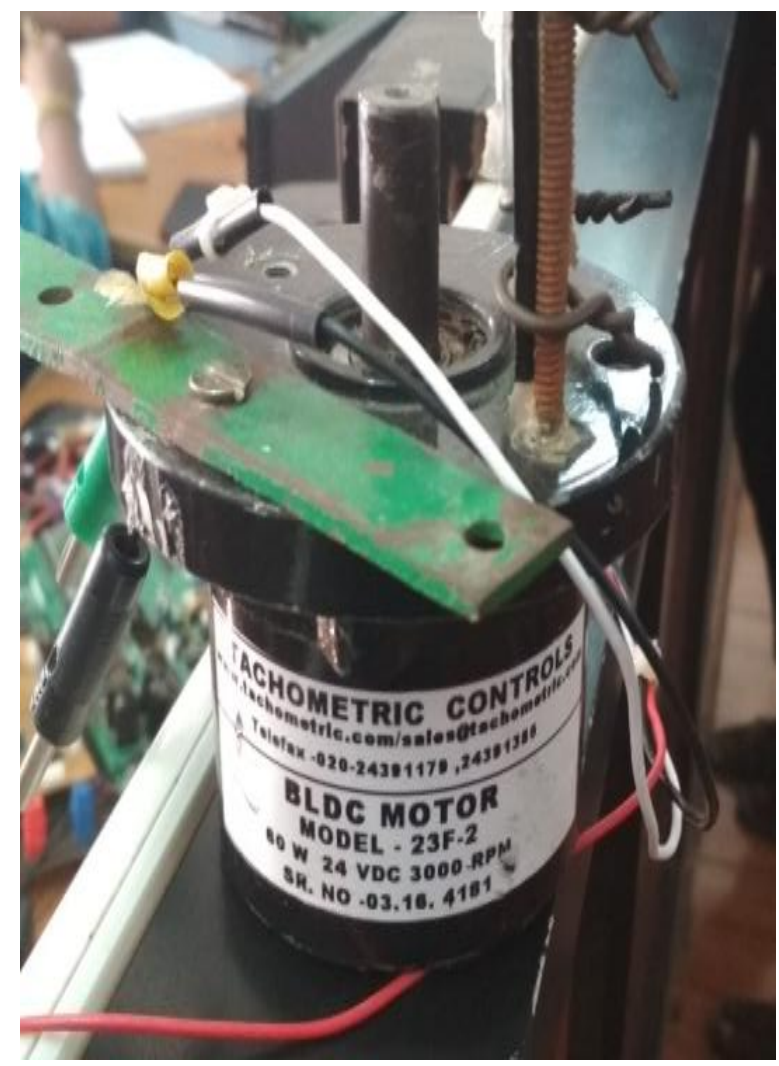

Fig.10 BLDC motor of 60W, 3000rpm, 24V

The figure shows the motor which is BLDC of $24 \mathrm{~V}$, $3000 \mathrm{rpm}, 60 \mathrm{~W}$ motor. which is having halsensors to detect the position of the rotor and helps the controller in switching the opposite windings. And it is provided with three wires for three phases and only two phases will be turned on at a time.

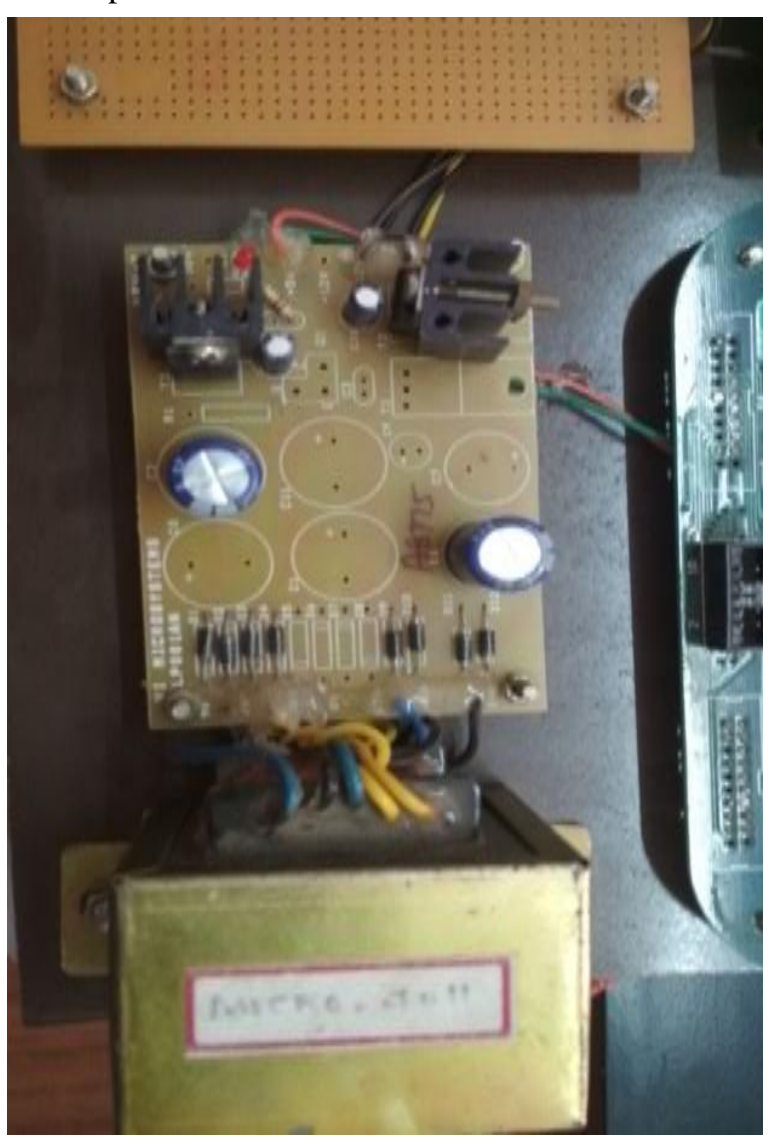

Fig 12 Step down transformer

The step down transformer of primary $230 \mathrm{~V}$ and the secondary $5 \mathrm{~V}$ is used to supply the power to the LV(Low Voltage) side.

The buffer circuit will be provided with refference speed and the actual speed of the motor with which it will generate the error signal by comparing the speeds.

\section{Stepdown-transformer $230 / 5 \mathrm{~V}$}

B. Buffer circuit

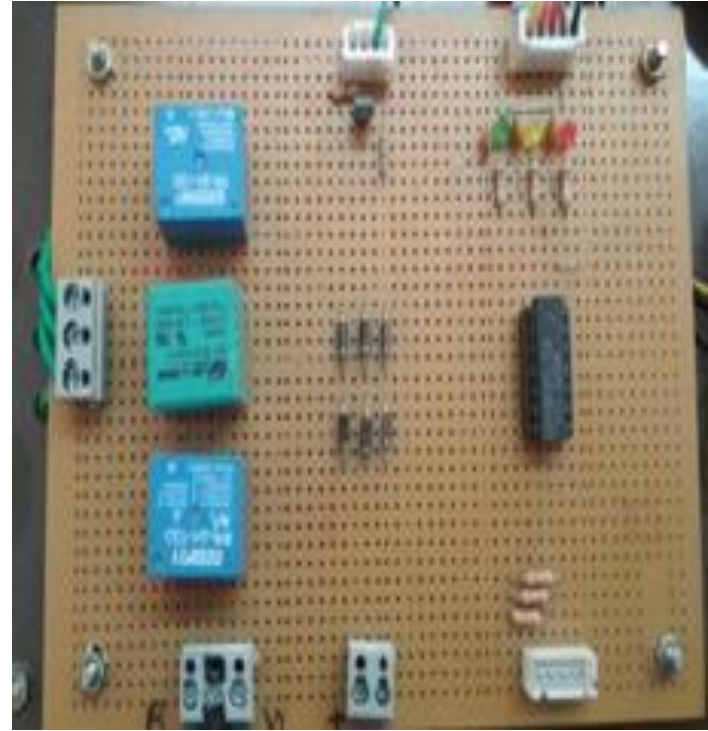

Fig.11 Buffer circuit 


\section{Driver Circuit}

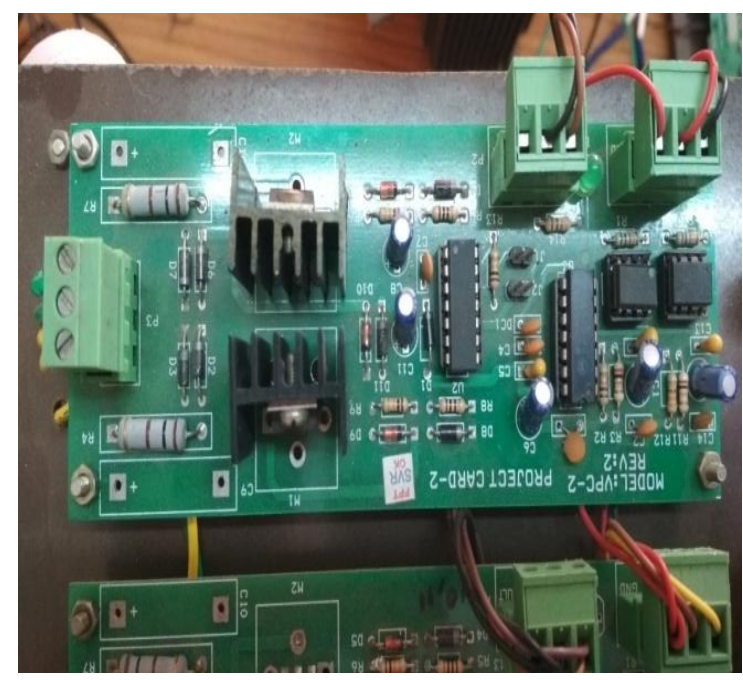

Fig.13 Driver circuit

The driver circuit consist of the components, Opto Coupler for isolations and two MOSFET switches for each Driver Circuit. To run the motor, 3 Drivers are required.

The hardware part consists of 1)BLDC motor 2) buffer circuit 3)step-down transformer 4)driver circuit

\section{E. Working}

The working of the system consists of at first the reference speed has to be given to the buffer by the touch pad. Now the controller generates the PWM pulses required to run the driver circuit with the signal received from the buffer circuit and according to the signal received to the driver the MOSFETS get on and off to make each phases of the BLDC motor. After that the speed of the motor gets tracked with that the error signal will be generated continually until the actual and the reference speed get matched.

\section{CONCLUSION}

Electric Vehicle is driven by PMBLDC Motor which is running through the PWM pulses generated by DSPIC Controller, the speed controlof the motor is good using fuzzy logic controller in Simulink which controls the required speed with less than the PI controller do. In hardware part DSPIC Controller which gets the feedback through hall sensor that sends the rotor position controls the speed of motor, by this efficiency of running vehicle increases. The controller consists ofEmbeddedprogram which controls the function of motor to drive, when the sensor gets activated the motor gives you alarm and the speed of the motor reduces automatically. Comparing to other electrical motor PMBLDC motor has less power consumption and it also generates high the regenerative power comparatively.

\section{REFERENCES}

1. IEEE TRANSACTIONS ON MAGNETICS, VOL. 41, NO. 1 JANUARY 2005509 A Controller of Brushless DC Motor for Electric Vehicle Hong-xing Wu, Shu-kang Cheng, and Shu-mei Cui.

2. Energy-Regenerative Braking Control of Electric Vehicles Using Three-Phase Brushless Direct-Current Motors Bo Long 1, Shin Teak Lim 2, Ji Hyoung Ryu 2 and Kil To Chong 2,Energies 2014, 7, 99-114; doi:10.3390/en7010099

3. Journal for Research | Volume 02 | Issue 04 | June 2016 ISSN: 2395-7549 All rights reserved by www.journalforresearch.org Brushless DC Motor Design for Electric Traction System Md. Bashir Sheikh Priti. S. Manware Priyadarshini Institute of Engineering \& Technology Priyadarshini Indira Gandhi College of Engineering.

4. Middle-East Journal of Scientific Research 24 (3): 734-739, 2016 ISSN 1990-9233 C IDOSI Publications, 2016 DOI 10.5829/idosi.mejsr.2016.24.03.23070Corresponding Author: Aarim C. Sijini, PG scholar, Power Electronics and Drives, Dr. Sivanthi Aditanar College of Engineering, India. 734 Switched Reluctance Motor for Hybrid Electric Vehicle Aarim C. Sijini, E. Fantin and L. Prakash Ranjit PG Scholar, Dr. Sivanthi Aditanar.

5. Energies 2014, 7, 99-114; doi:10.3390/en7010099energies ISSN 1996-1073 www.mdpi.com/journal/energies Article Energy-Regenerative Braking Control of Electric Vehicles Using Three-Phase Brushless Direct-Current Motors Bo Long 1, Shin Teak Lim 2, Ji Hyoung Ryu 2 and Kil To Chong 2.*.

6. Journal for Research | Volume 02 | Issue 04 | June 2016 ISSN: 2395-7549 All rights reserved by www.journalforresearch.org Brushless DC Motor Design for Electric Traction System Md Bashir Sheikh Priti. S. Manware Priyadarshini Institute of Engineering \& Technology Priyadarshini Indira Gandhi College of Engineering.

7. 0-7803-6401 -5/00/\$10.00 Q 2000 IEEE Advanced PM Brushless DC Motor Control \& System for Electric Vehicles Fang Lin \&, IEEE Senior Member and Hock Guan Yea Nanyang Technological University, Nanyang Avenue, Singapore 639798 Tel: (65) 790-5023, Fax: (65) 792-0415, email address: eflluo@ntu.edu.sg.

8. 2011 International Conference on Recent Advancements in Electrical, Electronics and Control Engineering Practical Implementation of Four Quadrant Operation of Three Phase Brushless DC Motor using dsPIC, Sheeba Joice, C. Dept. of EEE Dr. S.R. Paranjothi Dept. of EEE Dr. Jawahar Senthil Kumar.

9. IJCA Special Issue on "Computational Science - New Dimensions \& Perspectives" NCCSE, 2011, DSP based Speed Control of Permanent Magnet Brushless DC Motor, Vandana Govindan , Anish Gopinath, S.Thomas George Assistant Professor

10. Proc. IEEE Conference on Emerging Devices and Smart Systems (ICEDSS 2017) 3-4 March 2017, Mahendra Engineering College, Tamilnadu, India. 978-1-5090-5555-5/17/\$31.00 (C2017 IEEE 229 Modeling and Simulation of Closed Loop Speed Control for BLDC Motor P.Suganthi, S. Nagapavithra, S. Umamaheswari

11. IEEE TRANSACTIONS ON MAGNETICS, VOL. 45, NO. 10, OCTOBER 2009, PM Synchronous Motor Speed Control Using Hybrid Fuzzy-PI With Novel Switching Functions Amit Vilas Sant and K. R. Rajagopal.

12. 10.1109/TIA.2016.2522943, IEEE Transactions on Industry ApplicationsBLDC Motor Driven Solar PV Array Fed Water Pumping System Employing Zeta Converter Rajan Kumar, Member, IEEE, and Bhim Singh, Fellow, IEEE.

13. M.Vanitha*et al. /International Journal of Pharmacy \& Technology IJPT| Dec-2016 | Vol. 8 | Issue No.4 | 26426-26432 Page 26426ISSN: 0975-766X .CODEN: IJPTFI Available Online through Research Article www.ijptonline.co EMERGENCY INFORMATION SHARING VIA MOBILE ALERT USING ARDUINO M.Vanitha School of Information Technology and Engineering, VIT University, Vellore, India. Email:mvanitha@vit.ac.in Received on 25-10-2016

Accepted on 02-11-2016

14. International Journal of Engineering Technology Science and Research IJETSR www.ijetsr.com ISSN 2394 - 3386 Volume 4 Issue 4 April 2017 Arduino based Car Security System Sayali Waranka Suraj Nawale Twinkle Bardeskar Amruta Mhatre Electronics and telecommunication Engineering Department,

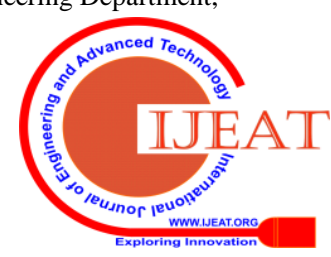


15. ISSN XXXX XXXX $\quad$ (c) $2017 \quad$ IJESC

Development of System for Early Fire Detection using Arduino UNO Digvijay Singh1, Neetika Sharma2, Mehak Gupta3, Shubham Sharma4 Student1. 2. 3. 4 Department of Electronics and Communication MIET Jammu, Jammu University, J\&K, India

\section{Author Profile}

D.Susitra is working as a Professor at Sathyabama Institute of Science and Technology, Chennai, India. She has received her B.E degree in Electrical and Electronics Engineering from Alagappa College of Engineering and Technology / Madurai Kamaraj University, Tamilnadu, India in 1995 and M.E degree from Sathyabama University, Tamilnadu, India in 2004. Her Research interest includes Renewable energy sources, modelling and control of electrical machines, power electronic converters and Artificial Intelligence Techniques. 